American Journal of Pharmaceutical Education 2017; 81 (6) Article S7.

\title{
CORRECTIONS
}

\section{Correction to Report of the 2016-17 Academic Affairs Standing Committee: Entrustable Professional Activities Implementation Roadmap}

\section{Correction to Student Self-Assessment and Faculty Assessment of Performance in an Interprofessional Error Disclosure Simulation Training Program}

Errors were made in the above articles that appeared in past issues of the Journal. The errors have been fixed and the corrected articles appear in the same issue they were originally published in.

Appendix 1 had format errors in "Report of the 2016-17 Academic Affairs Standing Committee: Entrustable Professional Activities Implementation Roadmap"

Amy L. Pittenger, PharmD, PhD, Debra A. Copeland, PharmD, Matthew M. Lacroix, PharmD, Quamrun N. Masuda, PhD, RPh, Peter Mbi, PharmD, PhD, Melissa S. Medina, EdD, Susan M. Miller, PharmD, Scott K. Stolte, PharmD, Cecilia M. Plaza, PharmD, PhD

Volume 81, Issue 5, Article S4

Appendices 1-3 were omitted from "Student Self-Assessment and Faculty Assessment of Performance in an Interprofessional Error Disclosure Simulation Training Program"

Therese I. Poirier, Junvie Pailden, Ray Jhala, Katie Ronald, Miranda Wilhelm, Jingyang Fan

Volume 81, Issue 3, Article 54 